\title{
GLOBALIZATION AND FINANCIAL CRISES
}

\section{Ivan LUCHIAN ${ }^{1}$, Associate Professor, PhD, International Institute of Management IMI-NOVA}

Financial globalization is the latest stage of financial internationalization process. It is presented as a financial interdependence of the countries that emerged due to the increasing number and volume of international financial transactions and international capital flows. The aim of the research is to demonstrate that some manifestations of financial globalization are key determinants of the international financial crises. Research methodology - in order to achieve the expected results, author applied recognized methods and techniques applied as economic investigations: comparative method, statistical method, logical analysis method. The research results, expressed by knowledge through mentioned dependencies enables forecasting of future international financial crises and developing mitigating measures both globally and in the Republic of Moldova.

Key words: financial globalization, financial crisis, financial market, capital flows.

Globalizarea financiară este cea mai recentă etapă a procesului de internaţionalizare financiară. Ea se prezintă în forma interdependenţei financiare a ţărilor, care a apărut datorită creşterii numărului şi volumului tranzacţiilor financiare internaţionale şi a fluxurilor internaţionale de capital. Scopul cercetării constă în demonstrarea faptului că unele manifestări ale globalizării financiare reprezintă principalii factori determinanţi ai crizelor financiare internaţionale. Metodologia cercetării în vederea obţinerii rezultatelor scontate, autorul a aplicat metode şi tehnici recunoscute şi aplicate în investigaţiile economice: metoda comparaţiei, metoda statistică, metoda de analiză logică. Rezultatele cercetării, exprimate prin cunoaşterea dependenţelor menţionate, permit prognozarea viitoarelor crize financiare internaţionale şi elaborarea de măsuri de atenuare a consecinţelor atât la nivel global, cât şi în Republica Moldova.

Cuvinte-cheie: globalizare financiară, criză financiară, piaţă financiară, fluxuri de capital.

Финансовая глобализаџия является последней стадией проиесса финансовой интернационализации. Она представлена в форме финансовой взаимозависимости стран, которые возникли в связи с увеличением количества и объема международных финансовых операций и международных потоков капитала. Целью исследования является доказательство, что некоторые проявления финансовой глобализации являются ключевыми определяютими факторами международных финансовых кризисов. Методология исследования - для достижения ожидаемых результатов, автор использовал признанные методы и приемы, применяемые в экономических исследованиях: сравнительный метод, статистический метод, метод логического анализа. Результаты исследования, заключенные в выявлении упомянутых зависимостей, дают возможность прогнозирования будущих международных финансовых кризисов и разработки мер по смягчению его последствий на глобальном уровне и в Республике Молдова.

Ключевые слова: финансовая глобализачия, финансовый кризис, финансовый рынок, потоки капитала.

JEL Classification: G01; G15.

Introduction. Globalization is a process in which the world is transformed into a single global system. The concept of financial globalization is bound to create a global currency markets, a global financial markets, a global financial system, whose content and development is based on the phenomenon of national financial markets deregulation, the emergence and development of new financial instruments and business expansion of banks and other international financial institutions.

\footnotetext{
1 @ Ivan LUCHIAN, luchian_ivan@mail.ru
} 
Financial globalization requires a growing volume of financial flows of capital and increasing their intensity, which is proportional to the degree of openness of national financial markets, the level of leverage and the level of financial integration.

At the same time, financial globalization events lead to serious imbalances in various segments of the local and international financial markets, which, in certain circumstances, trigger the financial crisis.

The essence of financial globalization. Financial globalization is the integration of the financial systems of individual countries with international markets and financial institutions [12, p. 357].

Financial globalization refers to the process by which financial markets from different countries are integrated into a whole. Financial globalization can be defined as the free movement of finances across national borders without facing any restrictions [1].

International financial crises overview. The financial crisis is a situation where the value of financial institutions or asset falls quickly. Financial crisis is often associated with panic or bankruptcy of banks, during which investors sell their assets or withdraw money from bank accounts with confidence that the value of these assets will drop if they remain at financial institutions [5].

The international (global) financial crisis is a profound dysfunction of the financial and credit system in a group of countries, which leads to substantial disparities in international credit and foreign exchange systems and interrupt their operation. Typically, the financial crisis comprises different spheres of the global financial system. Main promoter of financial crises is capital in cash and immediate form, lending institutions and public finances [14].

The global financial crisis occurs for reasons, that are not necessarily based on accurate information or apparent logic, and are conducted under the financial contract parties from many nations simultaneously reaching the conclusion that the contracts they hold are unlikely to be honored by counterparties or the financial assets they hold they are likely to be worth much less than previously thought [2].

According to scientists Reinhart and Rogoff, the period 1900-2010 was very specific event on the international financial crises (Figure 1) [9].

The last global financial crisis took place in the period of 2007-2008, which is known as the “Global Financial Crisis" or "Financial Crisis of 2008”. This crisis could lead to the total collapse of large financial institutions, but this has not occurred because of bank rescue measures of national governments, but stock markets, however, there has been a significant drop worldwide.

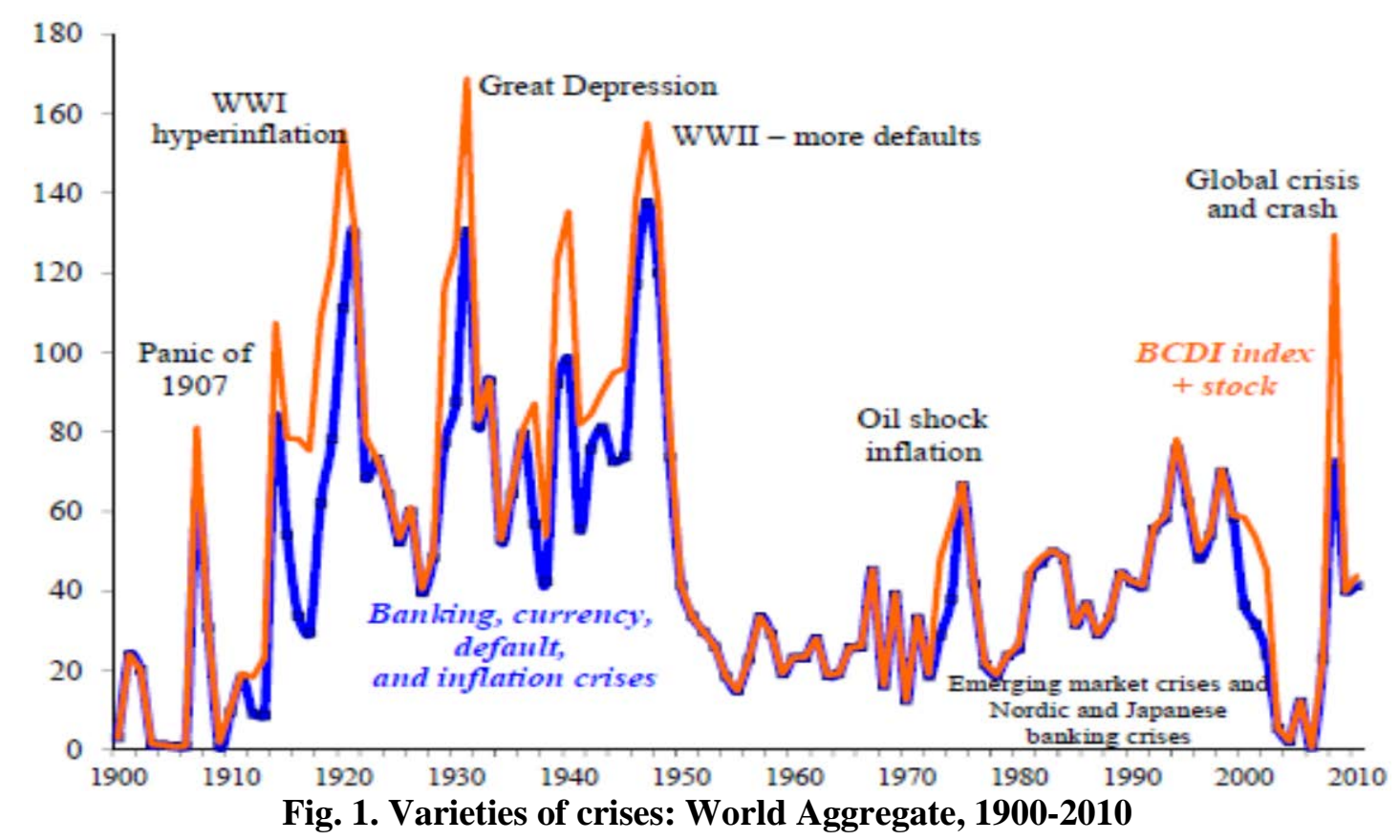

Source: [9].

Contagion effect was reflected in many other areas: housing market, labor market. The crisis played a role in the bankruptcy of many companies in the real sector of the USA, led to 2008-2012 global economic downturns and contributed to the European sovereign debt crisis [6]. 
Financial globalization characteristics as international financial crisis premises. Under the impact of financial globalization, the environment in which financial transactions are carried out has significantly changed, changing the very nature of operations. The impact of financial globalization on the likelihood of financial crises can be considered on the basis of a number of characteristic phenomena, which, on the one hand, are creatures of financial globalization, and on the other hand, are factors that increase the likelihood of financial crises.

Russian scientist Senikov considers that these phenomena can be attributed [16]:

1. Reducing the regulatory authority and capacity to monitor financial markets from both domestic and international regulators.

As a result of the liberalization of economic legislation and limiting state control significantly reduced the possibility of central banks and other national regulatory institutions to have a significant impact on the financial markets. This is particularly relevant to financial globalization impact on reducing the ability of national regulators to influence the policies of major players in the financial market, such as multinational corporations and transnational banks. At supranational regulators also lack the effective instruments of influence on financial market participants.

2. The liberalization of the legislation regulating the methods and rules of the financial activities.

A consequence of the large-scale liberalization of financial activities, which covered most of the countries in the world, has become a significant simplification of the implementation of international financial transactions. The result was an unprecedented increase in cross-country capital flows (Figure 2).

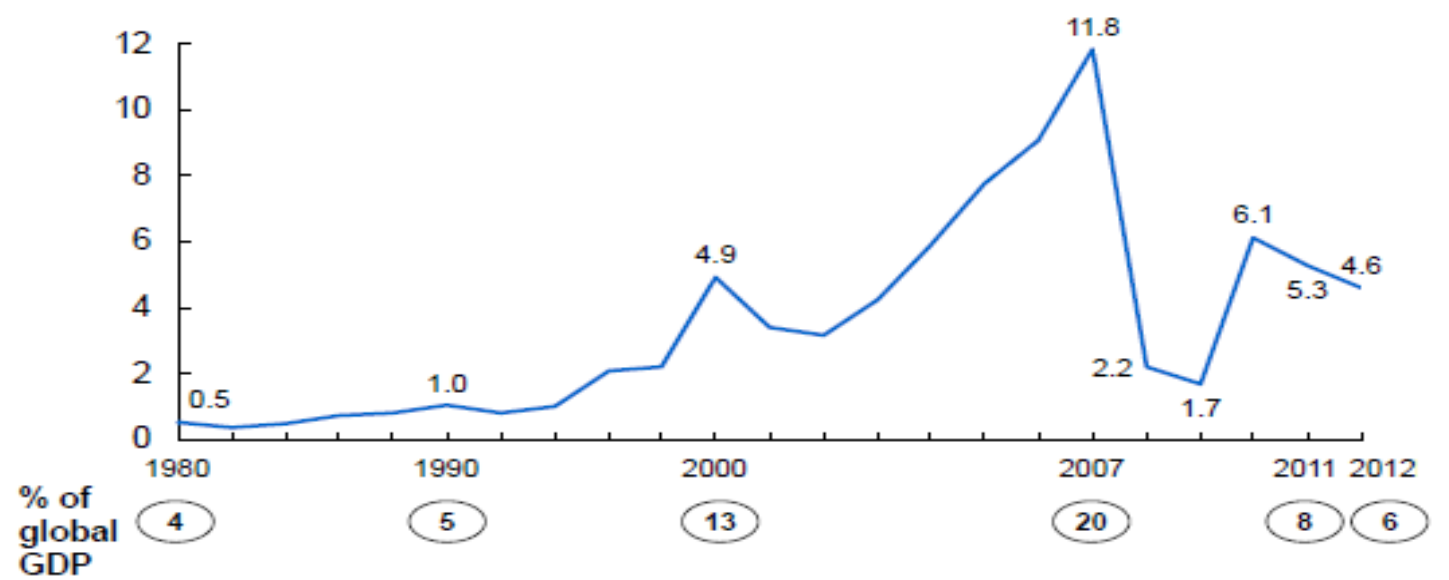

Source: [8].

Fig. 2. Cross-border capital flows

It specifies that international capital flows tend to rise sharply on the verge of financial crises. Thus, the amount of cross-border flows of 0,5 trillion USD level in 1980 increased to 4,9 trillion in 2000, then in 2007 - to 11,8 trillion USD. Along with it, was increased their share in world GDP at 4\%, strictly observe up to $13 \%$ and $20 \%$. But the onset of the international financial crisis, the value of cross-border financial flows tends to fall sharply.

It was also carried out the removal of the legislative distinction between the types of financial activities. Because of this, it was possible the emergence of financial institutions, combining the credit and investment function. As a result, a number of major financial companies operate at the same time in most parts of the financial market. This phenomenon leads to a significant increase in systemic risk, as the bankruptcy of a major financial institution can cause instability in a number of markets.

An important consequence of financial globalization has been the spread of securitization of banking and the use of derivatives. In view of these trends is much more complicated financial transactions and lost transparency.

Nowadays it is not always possible to establish the quality and reliability of assets which underlie the securities traded. Moreover, the use of derivatives by now reached a large scale.

In 2014 the global derivatives bubble was 20 percent bigger than in the last great financial crisis struck in 2008. It is a financial bubble far larger than anything the world has ever seen, and when it finally bursts it is going to be a complete and utter nightmare for the financial system of the planet. According to the Bank for International Settlements, the total notional value of derivatives contracts around the world has ballooned to an astounding 710 trillion USD [11]. 
3. The accumulation of substantial funds in a number of specific areas, free from the control of national legislation and supranational regulators.

As a result of financial globalization was formed a number of the world's financial centers, where due to favorable legislation and user-friendly infrastructure has focused a significant part of the financial market and the significant volumes of assets.

At the moment, there are in the world 83 international financial centers, which are grouped in a top perfected under the Global Financial Centres Index [3].

The importance of international financial centers, in large part, are the result of financial consolidation, primarily nationally and then globally. Thus, by the end of 1997, 25 cities world circuit controls 83 percent of shares in the world under institutional management and accounted for about half of global market capitalization (around 20,9 trillion USD). London, New York and Tokyo hold a third of the shares managed institutional and about 58 percent of global foreign exchange market [10].

In addition to the world's financial centers emerge and develop offshore and free economicareas , where capital flows are substantially free from the control of national regulators. As a result of financial globalization, has considerably increased the amount of funds held by individual and commercial financial institutions increasing the assets of institutional investors (pension, insurance, mutual and hedge funds).

In particular, global Hedge Funds' assets under management increased from 30 billion USD in 1990 to 1,4 trillion USD in 2005 [16] and hit a new high of 2,3 trillion USD in 2014 [4].

As a result, to date, a situation in which the total capital of the financial markets is larger than the size of foreign exchange reserves of the central banks of the world. It should be noted that the activities of hedge funds pose a threat to financial stability, as a high-risk, non-transparent and virtually free of government regulation.

4. A significant increase in the size of short-term speculative trading in financial markets.

As a result of liberalization legislation and the significant expansion of the financial markets has increased the possibility of short-term profit at the expense of the speculation. The bulk of transactions in the financial markets currently have a short-term, linked to the ultra-mobile speculative capital flows depending on subjective psychological factors that determine the behavior of investors.

These factors, in turn, are often irrational. Also, in the present conditions prevalent behavior caused a crisis of confidence, which is reflected in the mass changes in the market by agents of its financial position under the influence of negative news about the changes in market conditions. Large volumes of funds move as soon as possible under the influence of irrational psychological factors.

Focusing on making a profit from short-term speculative transactions on the exchange rate, or speculation on the international stock market, speculative capital may undermine both the activities of individual companies and entire countries and economic regions (provoking a collapse of the stock market, causing strong fluctuations of exchange rates) [17].

As a result of grew instability in the international financial system increases the likelihood of financial crises.

5. A significant increase in systemic risk.

As a result of financial globalization, the degree of correlation of the financial markets has significantly increased, this is manifested in a significant increase in the mutual influence of national and international financial markets. That is, in the modern financial system, the emergence of financial instability and crisis on a particular financial market or in a particular national economy are more likely to lead to the spread of the crisis on the financial systems of other countries and may acquire a global character.

Some authors point to the problem of the concept of innovation and investment nature of globalization are associated with the uncertainty of the outcome and the uneven development of the innovation process, which are the major risk factors associated with an acceleration of structural reforms in the national economy, the increasing number of mergers and acquisitions [13], [15].

Conclusions. Those related confirm the existence of dependencies between conducting financial globalization process and triggering international financial crises. The survey shows that the pursuit of global financial processes admits prediction of the global financial crisis. They also suggest the need to improve the international system of global financial market regulation and financial policies adaptation to new realities domestic crisis. 


\section{REFERENCES}

1. ARESTIS, P., BASU, S. Financial Globalization and Regulation. Working Paper. 2003, no. 397, December [accesat 14 iulie 2015]. Disponibil: http://www.levyinstitute.org/pubs/wp397.pdf

2. Definition of global financial crisis [accesat 14 iulie 2015]. Disponibil: http://lexicon.ft.com/Term?term=global-financial-crisis

3. Global Financial Centres Index [accesat 14 iulie 2015]. Disponibil: http://en.wikipedia.org/wiki/Global_Financial_Centres_Index

4. Global Hedge Fund AUM Touches \$2.3 Trillion. 2015, 21 january [accesat 14 iulie 2015]. Disponibil: http://www.valuewalk.com/2015/01/global-hedge-fund-aum/

5. Financial Crisis [accesat 14 iulie 2015]. Disponibil: http://www.investopedia.com/terms/f/financialcrisis.asp

6. Financial crisis of 2007-08 [accesat 14 iulie 2015]. Disponibil: http://en.wikipedia.org/wiki/Financial_crisis_of_2007\%E2\%80\%9308

7. Institute of Bard College, Working Paper No. 397, December 2003 [accesat 14 iulie 2015]. Disponibil: http://www.levyinstitute.org/pubs/wp397.pdf 1

8. LUND, S., DARUVALA, T. et al. Financial globalization: Retreat or reset? 2013, march [accesat 14 iulie 2015]. Disponibil:

http://www.mckinsey.com/insights/global_capital_markets/financial_globalization

9. REINHART, C.M., ROGOFF, K.S. Financial and Sovereign Debt Crises: Some Lessons Learned and Those Forgotten. 2013, December [accesat 14 iulie 2015]. Disponibil: http://www.parisschoolofeconomics.eu/IMG/pdf/2014_05_28_rogoff-2-imf.pdf

10. SASSEN, S. Global Financial Centers. 1999, January-February [accesat 14 iulie 2015]. Disponibil: http://www.foreignaffairs.com/articles/54623/saskia-sassen/global-financial-centers

11. SNYDER, M. The Size of the Derivatives Bubble Hanging Over the Global Economy Hits a Record High. 2014, 27 May [accesat 14 iulie 2015]. Disponibil: http://www.globalresearch.ca/the-size-ofthe-derivatives-bubble-hanging-over-the-global-economy-hits-a-record-high/5384096

12. URSU, S. Implicaţii ale globalizării financiare asupra finanţării firmelor. In: Analele Ştiinţifice ale Universităţii “Alexandru Ioan Cuza”. Iaşi, 2004/2005, pp. 357-363 [accesat 14 iulie 2015]. Disponibil: http://anale.feaa.uaic.ro/anale/resurse/50\%20Ursu\%20SImplicatii\%20ale\%20globalizarii\%20financiare\%20asupra\%20finantarii\%20firmelor.pdf

13. ГЛУЩЕНКО, В.В. Финансовые риски в условиях глобализации. В: Финансы и кредит. 2006, № 19 , cc. 19-25.

14. ЛОМАКИН, В.К. Мировая экономика. 3-изд. Москва: ЮНИТИ-ДАНА, 2007. 672 с. [accesat 14 iulie 2015]. Disponibil: http://yourlib.net/content/category/36/96/105/

15. МАКСИМОВСКАЯ, М.В., ШАРОХО, Ю.Н. Мировой финансовый кризис в условиях глобализации. Москва, 2009 [асcеsat 14 iulie 2015]. Disponibil:

http://webcache.googleusercontent.com/search?q=cache:Fl4RgZtMLlkJ:www.mosveo.ru/images/stor ies/mirfinkrizis.doc $+\& \mathrm{~cd}=2 \& \mathrm{hl}=\mathrm{ru} \& \mathrm{ct}=\mathrm{clnk} \& \mathrm{gl}=\mathrm{md}$

16. СЕНЬКОВ, М.И. Финансовая глобализация как причина роста вероятности возникновения финансовых кризисов. В: Известия Иркутской Государственной Экономической Академии. 2012, № 1 [accesat 14 iulie 2015]. Disponibil: http://eizvestia.isea.ru/pdf.aspx?id=14227

17. Формы и последствия международной миграции капитала [accesat 14 iulie 2015]. Disponibil: http://economytoday.ru/litres/economy/index.php

Recommended for publication: 21.07.2015 